\title{
Extent of ICT Application in the Management of Administrative and Student Personnel Records in the Public Universities in Enugu State, Nigeria
}

\author{
Roseline Unoma Chidobi ${ }^{1, *}$ \\ ${ }^{1}$ Department of Educational Foundations, Enugu State University of Science \& Technology (Esut), Nigeria \\ *Correspondence: Department of Educational Foundations, Enugu State University of Science \& Technology (Esut), \\ Nigeria. Tel: 234-806-843-9262. E-mail: Chidobiroseline123@Yahoo.Com
}

Received: July 4, $2015 \quad$ Accepted: July 18, $2015 \quad$ Online Published: August 9, 2015

doi:10.5430/wje.v5n4p64 URL: http://dx.doi.org/10.5430/wje.v5n4p64

\begin{abstract}
The purpose of the study is to identify the extent of ICT application in management of administrative and student personnel record in the public universities in Enugu state. The study was a survey research the quantitative data were collected through a 20 - item questionnaire title "Extent of ICT Application in Record management (EIAMASPR). This was administered on a sample size of 605 respondents made up of university academic staff and senior Administrative staff. The data were analyzed using mean, standard deviation and t-test statistics on a modified 4 point rating scale. Findings of the study revealed among others that Information Communication Technology (ICT) are not adequately applied in the management of both administrative and student personnel record in the Universities in Nigeria. The study recommended that the use of ICT in record management should be enhanced in order to achieve effective school management.
\end{abstract}

Keywords: Information Communication Technology, University, Administrative, Student Personnel, Record Management

\section{Introduction}

University institutions are one of the tertiary institutions. It is at the apex in the hierarchy of educational institutions offering post secondary education. There are three government owned universities in Enugu state, they are university of Nigeria Nsukka (UNN), Enugu State University of Science and technology (ESUT), and National Open University of Nigeria (NOUN). All these universities have a lot of records to be kept and human beings are involved in managing these records. The two groups of persons involved are: Academic staff and non- academic staff which are referred to recently as administrative staff. All these staff personnel are involved in the management of records.

School management especially as regards to higher institution has become a difficult task in view of complexity of modern educational system in Nigeria. As the societal demands and need kept on changing and educational system embraces innovations. Also there is worldwide technological development, which has invariably affected all areas of administration in education. School record management which is an aspect of school management was not left out in this innovation and change. School administrators have now discovered that the traditional methods of managing schools especially in the area of record management which involves carrying files all about are not appropriate to handle the accelerating change. School management is not an easy task, because every administrative task area needed to be effectively managed. These areas according to Liphan and Hoe (1974) in Chidobi (2007) are arranged in zones:

Zone A - Management of programmes of instruction

Zone B - Staff personnel management

Zone C - Student personnel management

Zone D - Finance and physical resources management

Zone E - School community relationship management 
Record management is the keeping, storing retrieved and use of all the information in the school. Etesike (2008) opined that record is recorded information produced or recorded in the initiation, conduct or completion of any institutional or individual activity and that comprises content, context and structure sufficient to provide evidence of the activity. In other words, record is the documented evidence of the activities in the institution. Nworgu (2006) gave the concept of record management as the practice of maintaining the record of an organization like the school from time they are created up to their eventual disposal.

Summarily, record management is the ability to arrange and maintain all the school records which are kept for retrieval of information when need be. To manage the records of all areas of school administration should have been difficult but with fast growing world in the science and technology, everything is being done with the help of internet.Effective management of records cannot be achieved without sound knowledge of Information and Communication technology (ICT).

Information and communication technology according to Murdic and Ross (1971) as cited in Nwangwu (2005) is the process in which information (in-put) is recorded, stored and retrieved (processed for decision (output) on planning, coordination and controlling. Alkadi (2004) stated that information communication technology focused an understanding the processes, systems and mechanisms pertaining to information storage, absorption, transfer, presentation and processes through understanding the scientific principles in school management in tertiary institutions. Information and communication Technology (ICT) according to Ololube, Ossai and Ubogu (2006) in Edu, Sule\&Nsor (2015) opined that:

$$
\begin{aligned}
& \text { Information and communication Technology } \\
& \text { (ICT) are advances in Technology that provides } \\
& \text { a rich global resource and collaborative } \\
& \text { environment for dissemination of ICT } \\
& \text { literacy materials, interactive discussions, } \\
& \text { research information and international } \\
& \text { exchange of ideas, which are critical } \\
& \text { for advancing meaningful educational } \\
& \text { initiatives, training high skilled labour } \\
& \text { force and understanding issues related to } \\
& \text { economic development. }
\end{aligned}
$$

Some of the ICT facilities are found in the National Universities Commission recommendations guideline (2008) CDROM, DVD or VSB Sticks, e-book, are also suitable for record keeping. Others are computer and Telecommunication. Don (1987) cited in Ngene and Ekemezi (2004) stated that computer as a programmable electronic device that possesses a processor, memory and input/output facilities. Also they opined that telecommunication as another indispensable resources of ICT. According to them telecommunication is the science and technology of communication by telephone, radio, television etc. which according to Kwungwu (2004), are information and communication technology (ICTs) are used to describe a wide range of new technologies and their applications such as telephone, internet, world wide web (www) and e0mail etc which can be used to store records and process information.

Information and communication technology (ICT) can be categorized into five basic types according to Iwu (2000) citing in Landan (2001) and in Victor (2006). They are sensing technologies, communication technologies, display technologies, analysis technologies and storage technologies.

Sensing Technologies: these are the equipment that gather data or information and translate them into forms that can be understood by the computer. These sensing technologies include sensor, scanner, keyboard, mouse, electronic pen, touch or digital board, bar code sensor or reader, voice recognition system etc.

Communication Technologies: These are equipments that enable information to be transferred from the source to user. They also try to overcome natural barriers to information transfer like speed and distance. Some of this equipment includes facsimile machine (fax), telecommunication systems, telephone, e-mail, internet, teleconferencing, electronic bulletin boards, etc.

Display Technologies: These are output devices that form the interface between sensing, communication and 
analyzing technologies and their users. They include computer screen (visual display unit (VDU) or monitor printer, television etc.

Analysis Technologies: these are technologies that help in the investigation or querying of data, analysis, in-depth query for answers from simple to complex phenomena in research procedures.

Storage Technologies: These technologies facilities that efficient and effective storage of information in a form that can be easily accessed. They include magnetic tapes, disks, CD Roms, optical disks, cassettes, etc.

Specifically Ojo and Ugwuanyi (2006) identified different forms of ICTs facilities that can be used to ensure school management especially as it concern record management. They include the following:

Websites: A Website is a collation of related web documents that a web server makes available to the public. Typically a website contains an index page or home page that displayed automatically when a user enters the site at its top level.

E-mail: This simply means electronic mail. It is accessed via the internet and it provides an instant way to send or receive correspondence.

Compact Disk: Read-only memory (CD-ROM): CD-Rom is an optical-disk format that is used to hold prerecorded text, graphics and sound. Like music CDs, CD-Rom is a read and only disk. Read only means that the manufacturer cannot be written to or erases by the user. CD-ROM disk can hold up to 650 megabytes of data, equal to 300, 000 pages of text.

Internet: This is one of the most important ICT facilities. According to Ekemezie and Ngene (2004), the world internet is derived from international network, which has the largest computer network in the world. Internet services are usually on the airwaves and can only be downloaded by a local carrier or internet service provider. The internet contains information on virtually everything and there is abundance of knowledge available on the internet.

All the above are not adequately available in the higher institution, that is why Nworgu (2006) posits that government should increase financial allocation to education. He insisted that both federal and state government should increase allocation to education section and equip higher institutions under their case with basic ICT facilities such as enough computers and internet facilities. this is because the $21^{\text {st }}$ century is creating the environment for an emerging high technology age at almost the same speed of light.

Eze (2012) revealed in his work that many kinds of software are available in the world of computers and internet which will help in making the task of school management to become easy. In support of the above Odo (2003) reported that the school management software is a computerized application and programme which helps in effective and controlling the running of the operations of a school, such as storing, controlling and centralizing all the activities of the school. This software can equally be used in keeping record of all the data and events in the school which can be retrieved when needed. To buttress the above Stephen (2013) highlighted that there are many benefits accrue from the use of these software in school management includes:

(1) The annual student data is organized in a simple and accessible format.

(2) Translucent and federal management of multi disciplinary schools institution can be done easily with the help of this software

\subsection{Application of ICT for Record Management in the University}

Nworgu (2006) classified university records under the following subheadings (1) Management records (2) Administrative record (3) Students Record.

The management of record in the university setting in Nigeria is similar to the organigram.

The question is how to use ICT in recording all the events in the university. Using ICT to display the organizational chart. Generating management information and receiving them. ICT resources should be used to record meetings proceeding and decisions made.

The second type of record is Administrative records they including staff personnel records and physical resource record. Here ICT facilities will be used in recording all documents pertaining to personnel leave records, personnel duty roster and inventory of all the physical resources record like furniture stored in the various offices classrooms laboratories and workshop.

Finally using ICT facilities to record, the students personnel data like admission data, type of programme which includes sandwich, part - time programmes, evening distance learning programmes. There is need to use ICT 
facilities in handling many volume of information which the university needs to handle. Ironically, many of the tertiary institutions in Nigeria and Enugu in particular still use manual typewriters, to produce letters which the output cannot compare favourably with that of computer. Akukwe (2003) identified some importance of computer to record management which ensures effective school management to include:

It helps to promote and maintain standard and quality of work at a higher level over time than manual labour.

It saves cost, time and labour.

It increases productivity and efficiency.

In view of the above benefits that the researcher was challenged to ask what are the extent of application of (ICT) in record management.

\subsection{Statement of Problem}

The inefficient way by which records are managed in our universities is of great concern to well meaning Nigerians especially the stack holders of university education in Enugu state. People are worried in the way documents get lost, lost of files in the hands of termite destruction, fire incidence etc. Evidence from literature has shown that vital records in the universities in Nigeria especially in Enugu state are not well managed. Some results and scripts got missing as a result of poor record management. Students kept taking examination time out of number to no avail. Admission records and even students files are affected. This has always resulted in important information missing in students or staff files. Students results are manipulate falsification of admission process and impersonation. This nefarious practices has destroyed the image of Nigerian tertiary institutions including universities (Etesike 2008).

This has necessitated this study, and the researcher is challenged to ask; to what extent does universities in Enugu state apply ICT facilities in the record management such as administrative and student personnel record.

\subsection{Purpose of the Study}

The main purpose of the study is to examine the extent of application of ICT facilities in the university management in the universities in Enugu state. Specifically the study will;

1. Examine the extent of application of ICT facilities in university administrative record management.

2. To identify the extent of the use of ICT in management of students record.

\subsection{Research Questions}

The following research questions were posed.

1. To what extent are ICT appliedin management of administrative records.

2. To what extent is ICT facilities applied in the management of student's record?

\subsection{Research Hypothesis}

1. There is no significant difference in the mean perception scores of academic staff and senior administrative staff on the application of ICT facilities in the management of universities administrative records in Enugu State.

2. Use of ICT facilities in the management of student's record is not statistically significant.

\section{Methodology}

Descriptive survey research design was employed for the study. This is because the opinion of the respondents was sought. The study was carried out in the three government owned universities in Enugu state. The population for the study comprises all the senior Administrative staff and all academic staff in the three government owned universities in Enugu state. Namely university of Nigeria Nsukka (UNN), (1882 academic and 2420 senior Administrative staff). Enugu state university of Science and Technology (ESUT) (760 academic and 800 senior administrative staff) and national Open University of Nigeria Enugu study centre (NOUN) all academic staff 19 and all administrative staff 49. The researcher adopted proportionate stratified random sampling techniques in order to ensure a true representation of the sample, $10 \%$ of the population strata were used to select the respondents. But for NOUN all the academic 19 and Administrative staff 49 were used. Thus, giving a sample size of 654 respondents. The instrument for data collection was 20- item researcher structured questionnaire of modified 4 - point rating scale with the following response mode, Very Great Extent (VGE), Great Extent (GE), Low Extent (LE), Very Low Extent (VLE) for research 1 and 2 weighted 4, 3, 2, 1 respectively for the two research questions. Validation of the instrument was 
done by three experts in the faculty of education. Crombach Alpha was used to determine the internal consistency of the items. This involved the conduct of pilot study with a sample of 30 respondents randomly selected from three private universities in Enugu state namely Caritas University, Renaissance university and Godfrey Okoye University all in Enugu state. An alpha of reliability index of 0.78 for cluster A and 0.82 for cluster B, and the overall reliability index of 0.80 was obtained, which was considered high enough for the study. Out of 654 copies of the questionnaire distributed only 605 was returned correctly, giving 93\% percent rate.

The two research questions were analyzed using mean and standard deviation. A criteria mean of 2.50 was used while t-test statistics were used to test the two hypotheses at 0.5 levels of significance. The decision rule is to accept the null hypothesis if the calculated t-test value is less than the critical value, otherwise it will be rejected.

\section{Results}

In answering the research question 1 , the items on table 1 below were considered.

Table 1. Mean and Standard Deviation of the Respondents on Extent of Application of ICT Facilities on Record Management of Administrative Records in Government Owned Universities

\begin{tabular}{|c|c|c|c|c|c|c|c|}
\hline \multirow[b]{2}{*}{$\mathrm{S} / \mathrm{N}$} & \multirow[b]{2}{*}{ Item statement } & \multicolumn{3}{|c|}{$\begin{array}{l}\text { Academic Staff } \\
\text { No } 255\end{array}$} & \multicolumn{3}{|c|}{$\begin{array}{l}\text { Senior Admin Staff } \\
\text { No } 350\end{array}$} \\
\hline & & $\mathrm{X}$ & SD & Decision & $\mathrm{X}$ & SD & Decision \\
\hline 1 & $\begin{array}{l}\text { Use of ICT facilities to record volumes of } \\
\text { management information. }\end{array}$ & 2.58 & 0.96 & LE & 2.17 & 0.88 & $\mathrm{LE}$ \\
\hline 2. & $\begin{array}{l}\text { Using ICT resources to generate management } \\
\text { information and retrieving them. }\end{array}$ & 2.60 & 0.83 & GE & 2.50 & 0.88 & GE \\
\hline 3 & $\begin{array}{l}\text { Using ICT resources to record meeting proceedings } \\
\text { at the management. }\end{array}$ & 2.29 & 0.97 & LE & 2.40 & 0.96 & $\mathrm{LE}$ \\
\hline 4 & $\begin{array}{l}\text { All decisions made at the management level should } \\
\text { be recorded with ICT facilities for easy retrieve. }\end{array}$ & 2.76 & 0.74 & GE & 2.73 & 0.89 & GE \\
\hline 5 & Recording of staff personnel nominal rolls. & 2.28 & 0.95 & LE & 2.22 & 0.91 & LE \\
\hline 6 & Having digital bulletin board. & 1.59 & 0.83 & LE & 1.99 & 0.77 & LE \\
\hline 7 & $\begin{array}{l}\text { Upload and download files relating to staff } \\
\text { personnel. }\end{array}$ & 1.80 & 0.48 & LE & 1.89 & 0.84 & LE \\
\hline 8 & $\begin{array}{l}\text { Recording staff personnel leave and duty roaster in } \\
\text { the system. }\end{array}$ & 2.47 & 0.87 & LE & 1.79 & 0.99 & LE \\
\hline 9 & $\begin{array}{l}\text { Inventory of all the physical resources records in } \\
\text { the ICT facilities. }\end{array}$ & 1.92 & 0.57 & LE & 2.00 & 0.78 & LE \\
\hline \multirow[t]{2}{*}{10} & Faculty website & 2.47 & 0.85 & LE & 2.20 & 0.72 & LE \\
\hline & Grand mean & 2.26 & 0.81 & LE & 2.19 & 0.86 & LE \\
\hline
\end{tabular}

The result obtained indicated that responses from the two categories of respondents agreed that 8 items were not applied in the management of administrative records. In the government owned universities in Enugu State.

These items were $1,3,5,6,7,8,9$, and 10 . The items have means that range from $1.59-2.47$. The means of these items are below the benchmark of 2.50. The grand means of both categories are equally low, which were 2.26 for academic staff and 2.19 for senior Administrative staff. This shows that ICT facilities are not properly used for administrative record management in the public universities in Enugu state.

On the other hand, 2 items namely items 2 and 4 were accepted to a great extent that ICT is applied in managing administrative records. These items have means above 2.50 benchmark. Judging from the grandmean scores, public universities in Enugu state do not make use of ICT facilities to a reasonable extent, in the management of administrative records.

In answering the research question 2, the items on table 2 were considered. 
Table 2. Mean and Standard Deviation of Respondents on Extent of Application of ICT Facilities on Recording of Students Personnel Data

\begin{tabular}{|c|c|c|c|c|c|c|c|}
\hline \multirow[b]{2}{*}{$\mathrm{S} / \mathrm{N}$} & \multirow[b]{2}{*}{ Item statement } & \multicolumn{3}{|c|}{ Academic Staff $=255$} & \multicolumn{3}{|c|}{ Senior Admin Staff $=350$} \\
\hline & & $\mathrm{X}$ & SD & Decision & $\mathrm{X}$ & SD & Decision \\
\hline 11 & $\begin{array}{l}\text { ICT facilities like computer for recording of student } \\
\text { admission data. }\end{array}$ & 2.76 & 0.74 & GE & 2.73 & 0.89 & GE \\
\hline 12 & Types of programmes enrolled by students. & 2.28 & 0.95 & LE & 2.22 & 0.91 & LE \\
\hline 13 & Use of e - examination instead of pen and paper. & 1.68 & 0.66 & LE & 2.10 & 0.68 & LE \\
\hline 14 & Use of e-library or electronic learning. & 1.75 & 1.14 & LE & 2.11 & 0.67 & LE \\
\hline 15 & $\begin{array}{l}\text { Using examination scoring machine and storing all } \\
\text { manner of students results in the system. }\end{array}$ & 1.93 & 0.51 & LE & 2.36 & 0.68 & LE \\
\hline 16 & Using internet for student to browse their results. & 2.27 & 0.80 & LE & 2.35 & 0.83 & LE \\
\hline 17 & Provision of uninterrupted power supply (UPS). & 2.28 & 0.87 & LE & 2.33 & 1.01 & LE \\
\hline 18 & Having departmental computer laboratory. & 1.88 & 0.70 & VLE & 1.98 & 0.72 & LE \\
\hline 19 & Provision of satellite and cables. & 2.02 & 0.73 & LE & 1.99 & 0.73 & LE \\
\hline 20 & $\begin{array}{l}\text { Using power point and overhead projectors for } \\
\text { teaching and seminars. }\end{array}$ & 2.48 & 0.79 & LE & 2.20 & 0.89 & LE \\
\hline & Grand Mean & 2.13 & 0.79 & LE & 2.24 & 0.70 & LE \\
\hline
\end{tabular}

The result shows that responses from two respondents on 9 items agreed that ICT facilities are not used in the management of student personnel records. These items are 12, 13, 14, 15, 16, 17, 18, 19, and 20, including the grandmean. These mean ranging from $1.68-2.48$ were below the benchmark of 2.50 . While only item 11 with mean 2.76 agreed that ICT facilities like computer were used for recordingstudent's admission data.

$\mathrm{Ho}_{1}$ : There is no significant difference in the mean responses of the respondents on the extent of application of ICT facilities in the management of university records in Enugu state.

Table 3. T-test Statistical Analysis of the Responses of Academic and Senior Administrative Staff on the Extent of ICT Facilities in Record Management in Universities in Enugu State

\begin{tabular}{lllllllll}
\hline Variable & No & $\Pi$ & SD & DF & Prob. & t-table & t-cal & Decision \\
\hline Academic staff & 255 & 2.26 & 0.81 & 603 & 0.05 & \pm 1.96 & & \\
Senior Admin staff & 350 & 2.19 & 0.86 & & & & & \\
Total & 605 & & & & & & & \\
\hline
\end{tabular}

Table 3: above shows that the calculated t-test value of 0.819 is less than the t-table or critical test value of \pm 1.96 at .05 levels of significance and 603 degree of freedom. Thus, the null hypothesis is not rejected. This shows that there is no significant difference in the mean score of Academic staff and Senior Administrative staff on the extent of application of ICT facilities in record management in public universities in Enugu state.

The second hypothesis was tested as shown on table 4 below.

Table 4. T-test Statistical Analysis of the Responses of Academic and Senior Administrative Staff on the Factors Militating Against the Effective Utilization of E-learning

\begin{tabular}{lllllllll}
\hline Variable & No & $\Pi$ & SD & DF & Prob. & t-criti & t-table & Decision \\
\hline Academic staff & 255 & 2.13 & 0.80 & 603 & 0.05 & \pm 1.96 & 1.463 & NS \\
Senior Admin staff & 350 & 2.24 & 0.87 & & & & & Ho2 not rejected \\
Total & 605 & & & & & & & \\
\hline
\end{tabular}

Table 4 above revealed that calculated t-test value is 1.463 and is less than the t-critical test value of \pm 1.96 at .05 levels of significance and 603 degree of freedom. Thus, the null hypothesis is not rejected. This shows that there is no significant difference in the mean score of Academic staff and Senior Administrative on the extent of application of ICT facilities on recording of student personnel in the public universities in Enugu state.

\section{Discussion}

The responses to the first research question as indicated in table 1 revealed that almost all the respondents agreed that 
ICT facilities are not used in managing administrative record to a great extentthese records includes staff personnel record like personnel leave records, personnel duty roaster and inventory of all the physical resources.

These findings are in agreement with (2) where he reiterated that the absence of using ICT facilities in record management, especially as it concerns administrative records lead to manipulation and missing of vital records. Some records as regards to staff employment data cannot be found.

The findings in appendix II shows that almost all the respondents agreed that ICT facilities are not used in managing students records to a great extent. Student's records like admission data, student's results, disciplinary records and important documents may be missing in students file. Students results are manipulated, falsification of admission process etc. This nefarious practice has destroyed the image of Nigerian tertiary institutions including universities (2). The findings are in contrary to (7) identified importance of computer to record management.

Also the t-test on table 3 and 4 show that there are no significant difference between the mean scores of Academic and senior administrative staff on the extent of usage of ICT facilities in the universities administrative record and student personnel record management.

\section{Conclusion}

This study examined the extent of application of ICT facilities on record management in universities in Enugu state such as application of ICT facilitiesin the management of administrative record and student personnel records. The findings have a lot of implications to university education in the entire country. This is because if ICT facilities are not used to a great extent in record management, handling of records manually will not yield effective result. Records stand the chances of missing or being falsified.

\section{Recommendations}

Based on the findings of the study, the administrators should enhance the use of ICT facilities in recording both administrative records like staff personnel data and physical resource documents.

Recording of students personnel document manually or using analog is old fashioned and risky. Therefore, administrators should insist on using ICT facilities in keeping student personnel records like results, admission and displinary records.

Government, especially the visitors of the university should procure adequate ICT facilities to be used in record keeping.

Both administrative and students records should be moved to ICT unit, so that they should be recorded into the computer.

The entire university environment should have internet connection. In order to make it accessible to both administrative and academic staff personnel for record purposes.

\section{References}

Agbo, T.O. (2007). Office administration and management in contemporaryNigeria. Enugu: Leading Star Printing services.

Akukwe, A.G. (2003).Computer studies: An introduction. Owerri: Co Concepts Ltd.

Alkadi, O.S. (2004). Introduction to computer application. Ibadan: EducationalIndustries Nigeria Ltd.

Chidobi, R.U. (2007). Educational administration management and supervision(ed). Enugu: God's Will Printer Enterp.

Edu, M.I., Sule, S.A., \& Nsor, E.I. (2015). Open and Distance Learning (ODL)education in Nigeria: Challenges of academic quality. Paper presented at theInternational Scholarly and Scientific Research \& Innovation organized byWorld Academy of Science, Engineering \& Technology. London: $25^{\text {th }}-26^{\text {th }}$ May.

Etesike, C.N. (2008). Harnessing ICT resources for effective implementation of UBEscheme in Nigeria. A conference paper presented at the $7^{\text {th }}$ Internationalconference of National Assist for Research development FCT College ofEducation. Zuba October.

Igwe, D.O. (2012). The roles of ICT development in open and distance education:achievements, prospects and challenges. Africa Journal of Teacher Education (AJOTE), 2(2), Retrieved from 
https://www.journal.lib.uoguelph.ca/index.php/ajote/article/view/1827/2591

National universities Commission (2008). Guidelines for open and distancelearning in Nigerian universities. Retrieved from http://www.nuc.edu.ng/nucsit/file/ODL\%20REVISED\%20GUIDELINES\%20FOR\%20NIGERIA\%20UNIVER SITIES.pdf

Ngene, N.J., \& Ekemezie, W.N. (2004). Computer and information technology. Enugu: Kinsman publishers Ltd.

Nwangwu I.O. (2005). Personnel management in education: Human resources, administrative and development. Enugu His Glory Publication.

Nworgu, G. B. (2006). The Indispensability of ICT in educational research. In Eze, D.N. \&Nkedi O. (eds)., ICT in the service of education. Enugu: TIMEX.

Odo, C.N. (2013). Educational planning and national development: A Nigerian perspective. Lagos: Glory Publication.

Ojo, M.O., \& Ugwuanyi, C. (2005). Delivery message on HIV/AIDS using ICT in aworkshop held at F.C.E. Auchi.

Olarundare, S.A. (2006). Utilization of ICT in curriculum developmentimplementation and evaluation. A paper presented at the NationalConference on Information and Communication technology in the service ofEducation. University of Nigeria Nsukka May $15-18$.

Ololube, N.P., Ossai, A.G., \& Ubogu, A.E. (2006). ICT and distance education in Nigeria: a review of literature and accounts. Presented at $2^{\text {nd }}$ InternationalOpen and Distance Learning (IODL) Symposium, Eskisehir, Turkey, September $12-15^{\text {th }}$.

Reju, S.A., \& Adesina, A. (2009). Fundamentals of online examinations. Paper presented at a training workshop for academic staff on on-line examinationsystem for National Open University of Nigeria, at the Model Study CentreComputer Laboratory. Lagos 5 to 9 November.

Thurmond, V., \& Wambach, K, (2013). Understanding interactions in distanceeducation: A review of the literature. International Journal of Instructional Technology \& Distance Learning, 1(1).

Victor, N.N. (2006). Application of ICT to Library services: An essential resource for educational research. A conference paper presented at Institute of Education, UNN, Annual Conference. May. 